\title{
Safety and Effectiveness of Monochloramine Treatment for Disinfecting Hospital Water Networks
}

\author{
Isabella Marchesi ${ }^{1, *(1)}$, Stefania Paduano ${ }^{1}$, Giuseppina Frezza ${ }^{1}$, Luca Sircana ${ }^{2}$, Elena Vecchi ${ }^{2}$, \\ Pietro Zuccarello ${ }^{3}$, Gea Oliveri Conti ${ }^{3}\left(\mathbb{D}\right.$, Margherita Ferrante ${ }^{3}\left(\mathbb{D}\right.$, Paola Borella ${ }^{1}(\mathbb{D}$ and \\ Annalisa Bargellini ${ }^{1}$ (I) \\ 1 Department of Biomedical, Metabolic and Neural Sciences, Section of Public Health, University of Modena \\ and Reggio Emilia, Via Campi 287, 41125 Modena, Italy; stefania.paduano@unimore.it (S.P.); \\ giuseppina.frezza@unimore.it (G.F.); paola.borella@unimore.it (P.B.); annalisa.bargellini@unimore.it (A.B.) \\ 2 University Hospital Policlinico of Modena, Largo del Pozzo 71, 41124 Modena, Italy; \\ sircana.luca@aou.mo.it (L.S.); vecchi.elena@aou.mo.it (E.V.) \\ 3 Environmental and Food Hygiene Laboratory (LIAA), Department of Medical and Surgical Sciences and \\ Advanced Technologies "G.F. Ingrassia”, University of Catania, 95123 Catania, Italy; \\ pietro.zuccarello@unict.it (P.Z.); olivericonti@unict.it (G.O.C.); marfer@unict.it (M.F.) \\ * Correspondence: isabella.marchesi@unimore.it; Tel.: +39-059-2055460
}

Received: 29 July 2020; Accepted: 20 August 2020; Published: 22 August 2020

\begin{abstract}
The formation of potentially carcinogenic N-nitrosamines, associated with monochloramine, requires further research due to the growing interest in using this biocide for the secondary disinfection of water in public and private buildings. The aim of our study was to evaluate the possible formation of $\mathrm{N}$-nitrosamines and other toxic disinfection by-products (DBPs) in hospital hot water networks treated with monochloramine. The effectiveness of this biocide in controlling Legionella spp. contamination was also verified. For this purpose, four different monochloramine-treated networks, in terms of the duration of treatment and method of biocide injection, were investigated. Untreated hot water, municipal cold water and, limited to $\mathrm{N}$-nitrosamines analysis, hot water treated with chlorine dioxide were analyzed for comparison. Legionella spp. contamination was successfully controlled without any formation of N-nitrosamines. No nitrification or formation of the regulated DBPs, such as chlorites and trihalomethanes, occurred in monochloramine-treated water networks. However, a stable formulation of hypochlorite, its frequent replacement with a fresh product, and the routine monitoring of free ammonia are recommended to ensure a proper disinfection. Our study confirms that monochloramine may be proposed as an effective and safe strategy for the continuous disinfection of building plumbing systems, preventing vulnerable individuals from being exposed to legionellae and dangerous DBPs.
\end{abstract}

Keywords: monochloramine; disinfection by-products; N-nitrosamines; hospital setting; water networks; Legionella

\section{Introduction}

The control of Legionella contamination in complex water systems is still a critical issue, especially in healthcare settings where Legionella colonization of hot water systems is the primary risk factor for Legionnaires' disease [1]. National and international guidelines, aimed at preventing Legionella infections, recommend using biocides for contaminated hot water treatment [2,3]. To date, several physical and chemical disinfection methods have been proposed, but the most effective procedure has yet to be defined [4]. Chlorine-based disinfectants are cheap and widely used but they produce disinfection-by products (DBPs), which can pose potential health risks [5]. Exposure to DBPs is 
associated with an increased risk of cancer in humans and animals, and concerns regarding human reproduction and development [6,7]. Alternatives to chlorine such as chlorine dioxide, chloramines, ozone, and UV disinfection can be used. Chlorine and each of these disinfectants have different advantages and disadvantages in terms of cost, efficacy and stability, ease of application, pipe corrosion, and types of DBPs [8,9]. The DBPs of most concern include trihalomethanes (THMs) and haloacetic acids formed with chlorine, bromate formed during ozonation, and chlorite typically formed from chlorine dioxide treatment.

Monochloramine is a biocide that has long been used in the USA for the primary disinfection of municipal water supplies [10]. Some studies suggest that the introduction of monochloramine into a municipal water system represents the only community-based intervention that is capable of reducing the incidence of Legionnaire's disease associated with potable water [11,12]. Other studies report a lower prevalence of Legionella colonization in urban water supply systems, using monochloramine instead of free chlorine for disinfecting municipal drinking water $[13,14]$. On this basis, monochloramine has been used successfully for the secondary disinfection of hospital water networks [15-18] because it is less aggressive than chlorine and is more persistent in distribution systems. Chloramines produce lower DBP levels than chlorine [19], even if nitrogen by-products have been detected in chloraminated water, and there is much concern regarding nitrosamines due to their potential carcinogenic and genotoxic effects, even at nanogram doses [20-23]. The US Environmental Protection Agency (EPA) has listed six N-nitrosamines in the Unregulated Contaminant Monitoring Rule 2 (UCMR2) to be monitored from 2008 to 2010 by public water systems [23]. The World Health Organization (WHO), Health Canada, and the Australian National Health and Medical Research Council have established a guideline value for N-nitrosodimethylamine (NDMA) in drinking water (100, 40 and $100 \mathrm{ng} / \mathrm{L}$, respectively) [21,23]. The Ontario Ministry of the Environment and the California Department of Health Services set a more stringent notification level of 9 and $10 \mathrm{ng} / \mathrm{L}$ for NDMA, N-nitrosodiethylamine, and N-nitrosodiprophylamine. Similar permissible levels have emerged in some European Union (EU) member states, even if $\mathrm{N}$-nitrosamines are not specifically listed in the EU Drinking Water Directive [21].

The aim of our study was to evaluate the possible formation of N-nitrosamines and other DBPs in hospital hot water networks treated with monochloramine. The effectiveness of this biocide in controlling Legionella spp. contamination was also verified. For this purpose, four different monochloramine-treated networks, in terms of the duration of treatment and method of biocide injection were investigated. Samples of untreated hot water, municipal cold water and, limited to the $\mathrm{N}$-nitrosamines analysis, hot water treated with chlorine dioxide were analyzed for comparison.

\section{Material and Methods}

\subsection{Hospital Setting}

The study was conducted at the University Hospital Policlinico of Modena (Italy), a public 621-bed hospital consisting of a central nine-storey block and four separate buildings built between the 1970s and the 1990s. The same municipal water pipeline delivers water to all of the hospital buildings. A single main cold-water line branches out into several supply lines, each of which enters the water station of each hospital building. Once inside, cold water is heated using heat exchangers in order to produce hot water, which is moved in a water recirculating system. Three different water networks (A, B, and C) distribute hot water in parallel in the central block, while the other four buildings of the hospital have their own hot water pipelines (Figure 1A). Three monochloramine generators (Sanipur s.r.l., Brescia, Italy) are installed in the central block: Device 1 has been working on water pipeline $C$ since March 2009 while, in July 2015, Devices 2 and 3 were installed on pipelines A and B-which had both been previously treated with chlorine dioxide since 2005. A fourth monochloramine generator (Sanipur s.r.l., Brescia, Italy) has been in operation since July 2012, in Building E (four floors, 20 years old), which is mainly devoted to operating theatre activity. Monochloramine is produced in situ from the chemical 
reaction between stabilized sodium hypochlorite and an ammonium salt, and is then continuously injected into the hot-water return (Device 1-loop C, Device 2-loop A, and Device 4-loop E), or into the cold make-up water pipeline (Device 3-loop B), as described in Figure 1B. The target concentration of monochloramine was between 2 and $4 \mathrm{mg} / \mathrm{L}$ at distal points, in accordance with the US EPA guidelines, which established a maximum monochloramine concentration of $4 \mathrm{mg} / \mathrm{L}$ [24].
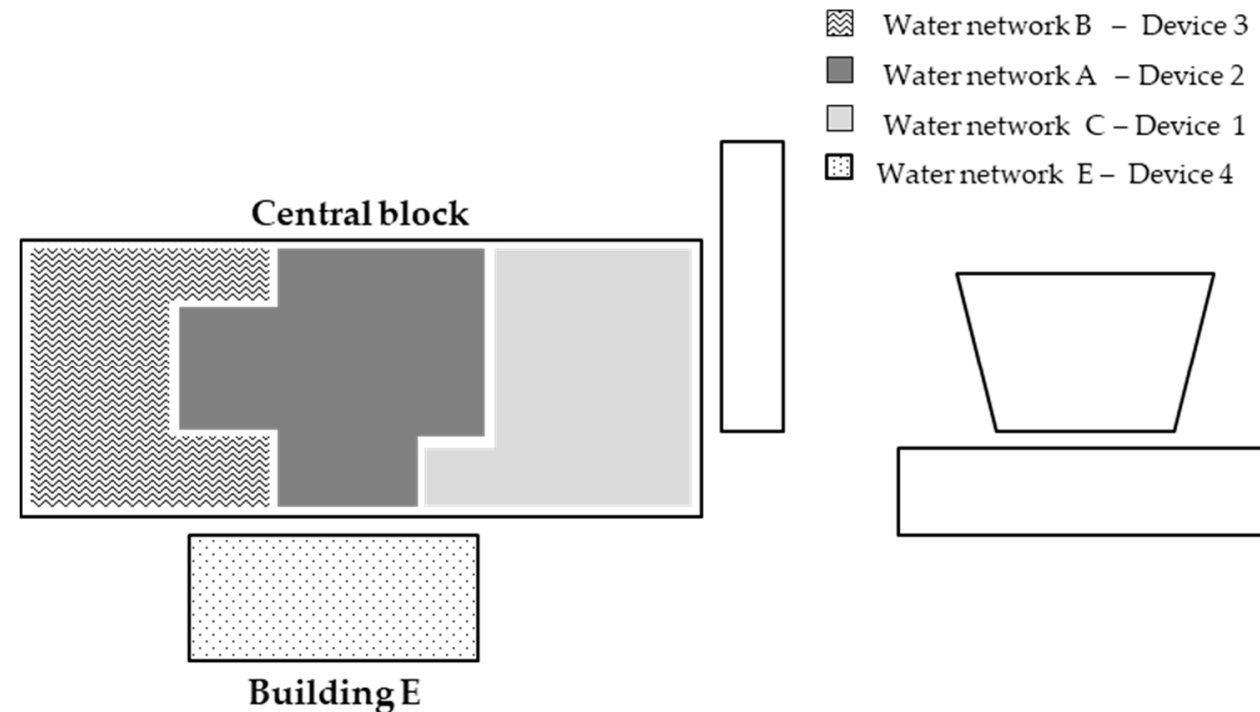

(A)
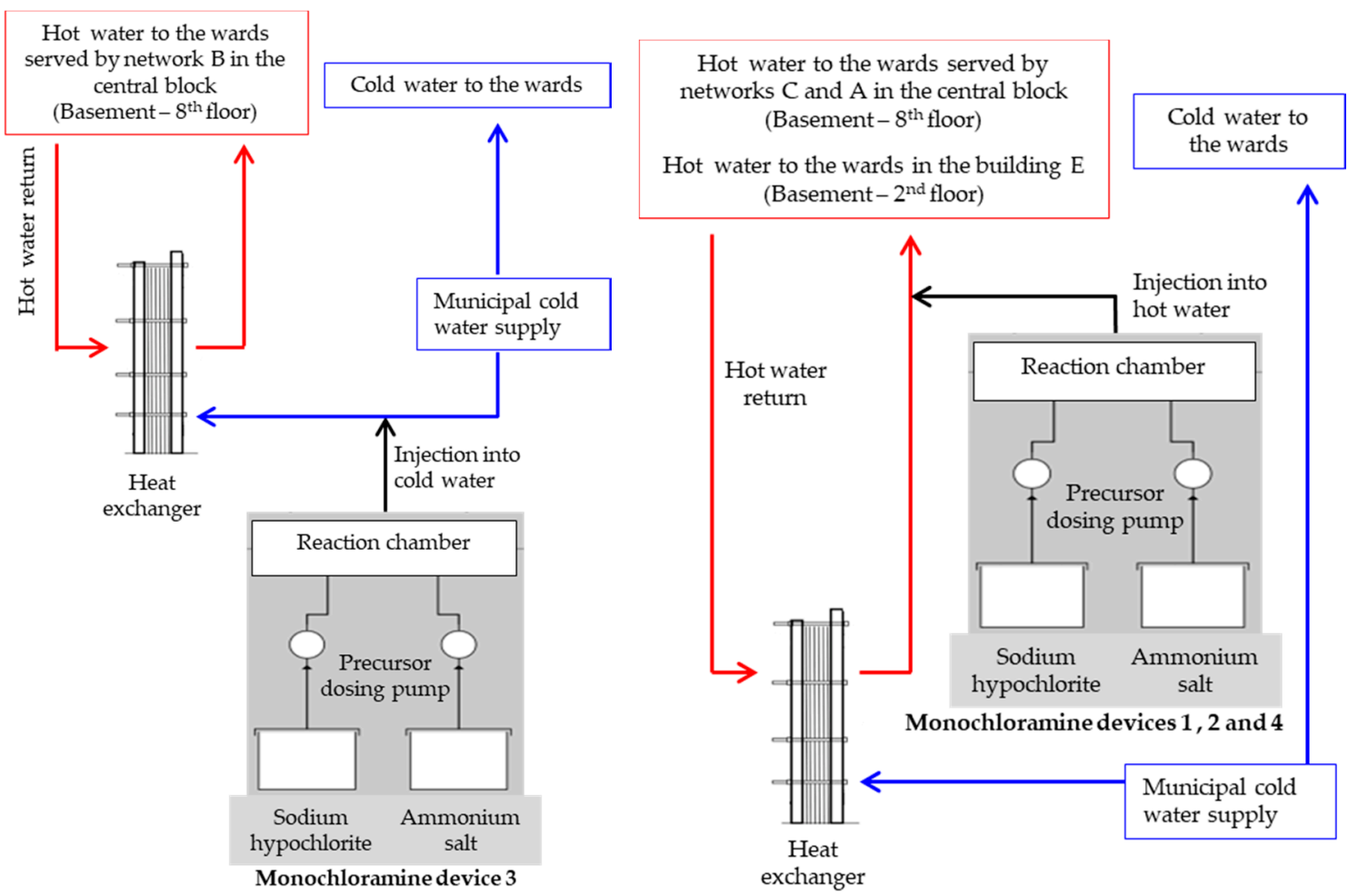

(B)

Figure 1. Schematic of hospital buildings (A) and monochloramine devices (B). White boxes in part A represent hospital buildings without monochloramine devices. 


\subsection{Sample Collection}

Over a 5 year period (January 2015-February 2020), 550 hot water samples (1 L) treated with monochloramine were collected from return loops and showers/taps for microbiological analysis, according to the hospital's Legionella sampling and management plan. The protocol scheduled sampling at, at least, one remote point every 50 beds, reiterating (every 3 or 6 months) the same sites (sentinel taps), and testing other outlets based on the Legionella risk assessment. Samples were collected, without flaming and after flushing for $1 \mathrm{~min}$, in sterile glass bottles containing sodium thiosulfate, in order to neutralize any residual disinfectant. At sampling, for each sample collected for Legionella testing, the water temperature (using a digital thermometer), $\mathrm{pH}$ (using a portable pHmeter), and monochloramine concentrations (using the Hach Lange indophenol method (Hach Lange, Milan, Italy); limit of detection (LOD) $=0.04 \mathrm{mg} / \mathrm{L}$ as combined chlorine) were measured.

Other chemical parameters such as chlorite, chlorate, total THMs, total organic carbon (TOC), nitrites, nitrates, and ammonia $\left(\mathrm{NH}_{4}{ }^{+}\right)$were measured on a more limited number of samples (about 20 samples/year) following the Legionella sampling program, with an increase in their monitoring for research purposes in the last period of the study, for a total of 136 water samples. The first sampling was performed when the chlorine dioxide devices were still operating in the A and B pipelines, and monochloramine had been working in pipelines C and E since 2009 and 2012, respectively. During each sampling session, a one liter sample was collected from the hot-water return loop of the four monochloramine-treated and one untreated networks, together with the cold water inlet to the hospital.

$\mathrm{N}$-nitrosamines were measured on water samples collected during the three sampling sessions specifically organized for this study (December 2019, and January and February 2020); water samples were taken from the hot-water return loop and the two distal taps of the four monochloramine-treated networks, for a total of 36 one liter samples (12 samples for session); simultaneously, a total of 24 one liter control samples (8 samples for the session) were collected from the hot-water return circuit and two distal taps of an untreated and a chlorine dioxide-treated network, together with samples of cold water taken from the pipeline at the entrance to the hospital central block and to the Building E.

Acid-preserved glass bottles were used for chemical determinations.

All water samples were returned to the laboratory immediately after collection and analyzed within $24 \mathrm{~h}$.

\subsection{Laboratory Methods}

\subsubsection{Microbiological Analysis}

Legionellae were isolated by a culture method in accordance with the ISO 11731:1998, as previously reported [15]. Briefly, $1 \mathrm{~L}$ of water was filtered (using a $0.2-\mu \mathrm{m}$-pore-size polyamide filter, Millipore, Billerica, MA, USA), the filtrate was suspended in $10 \mathrm{~mL}$ of the original sample water by vortexing for $2 \mathrm{~min}$, and $5 \mathrm{~mL}$ of the sample heat-treated. Two aliquots of $200 \mu \mathrm{L}$ of the original and concentrated samples (heat-treated and untreated) were plated onto a GVPC selective medium (Thermo Fisher Scientific, Waltham, MA, USA). The plates were incubated at $36 \pm 1{ }^{\circ} \mathrm{C}$ with $2.5 \% \mathrm{CO}_{2}$ for 10 days and analyzed on Day 4 with a dissecting microscope. Presumptive Legionella colonies were subcultured on BCYE (with cysteine) and CYE (cysteine-free) media (Thermo Fisher Scientific) and then incubated at $36 \pm 1{ }^{\circ} \mathrm{C}$ for $48 \mathrm{~h}$. Colonies grown on BCYE were subsequently identified to the species and serogroup levels using an agglutination test (Thermo Scientific ${ }^{\mathrm{TM}}$ Legionella Latex Test). The results were expressed as the number of colony forming units ( $\mathrm{cfu}$ ) per liter, and the LOD of the procedure was $25 \mathrm{cfu} / \mathrm{L}$. Only viable planktonic bacteria were enumerated.

\subsubsection{Chemical Analysis}

Chlorites and chlorates were analyzed using ion chromatography (the EPA method 300.1, LOD $=50$ and $60 \mu \mathrm{g} / \mathrm{L}$ for chlorites and chlorates, respectively), THMs (chloroform, bromodichloromethane, 
dibromochloromethane and bromoform) by gas chromatography (the modified EPA method 551.1 [25], LOD for each THM sample $=0.01 \mu \mathrm{g} / \mathrm{L}$ ), TOC by infrared spectroscopy (the APAT CNR-IRSA method 5040, LOD $=0.1 \mathrm{mg} / \mathrm{L}$ ), nitrites, nitrates, and free ammonia using specific colorimetric methods (Hach Lange, Milan, Italy). In detail, we used the diazotization method for nitrites (method 10019, LOD $=0.001 \mathrm{mg} / \mathrm{L}$ ), the chromotropic acid method for nitrates (method 10020, LOD $=0.2 \mathrm{mg} / \mathrm{L}$ ), the indophenol method for ammonia in the chloraminated samples (method 10200, $\mathrm{LOD}=0.02 \mathrm{mg} / \mathrm{L}$ ) and the salicylate method for ammonia in the monochloramine-free water (method $10023, \mathrm{LOD}=0.02 \mathrm{mg} / \mathrm{L}$ ).

Nine N-nitrosamines (N-nitrosodipropylamine (NDPA), N-nitrosodibutilamine (NDBA), $\mathrm{N}$-nitrosodiethylamine (NDEA), N-nitrosodimethylamine (NDMA), N-nitrosomorpholine (NMOR), N-nitrosopiperidine (NPIP), N-nitrosopyrrolidine (NPYR), N-nitrosodiphenylamine (NDPHA), and N-nitrosomethylethylamine (NMEA)) extracted with dichloromethane were measured using gas chromatography coupled to a mass spectrometer (EPA SW-846 Methods 3510C [26]). The LODs for each N-nitrosamine were: $2.3 \mathrm{ng} / \mathrm{L}$ for NPIP, $2.1 \mathrm{ng} / \mathrm{L}$ for NDEA, $2.0 \mathrm{ng} / \mathrm{L}$ for NDBA and NDMA, $1.8 \mathrm{ng} / \mathrm{L}$ for NDPA and NDPHA, $1.7 \mathrm{ng} / \mathrm{L}$ for NPYR, $1.0 \mathrm{ng} / \mathrm{L}$ for NMOR, and $0.9 \mathrm{ng} / \mathrm{L}$ for NMEA.

Italian and European legislations set the parametric values for drinking water at $700 \mu \mathrm{g} / \mathrm{L}$ for chlorite, $30 \mu \mathrm{g} / \mathrm{L}$ for the total THMs, $0.50 \mathrm{mg} / \mathrm{L}$ for nitrite and ammonium, and $50 \mathrm{mg} / \mathrm{L}$ for nitrate $[27,28]$. In Italy and in the EU, N-nitrosamines and chlorate are not listed in the Drinking Water Directive. Provisional standard values were proposed in the Netherlands (12 ng/L for NDMA), and in Germany (10 ng/L for NDMA and NMOR) [21]. The WHO established a provisional value of $700 \mu \mathrm{g} / \mathrm{L}$ for chlorate and a guideline value of $100 \mathrm{ng} / \mathrm{L}$ for NDMA in drinking water [29].

\subsubsection{Corrective Actions}

Corrective actions were taken to ensure that the proportions of the chlorine and ammonia precursors during the monochloramine formation were correct. These corrective actions included the draining/cleaning of the hypochlorite storage tanks, the frequent replacement with fresh products, use of a more stabilized hypochlorite solution (diluted, filtered, and $\mathrm{pH}$ adjusted), and monochloramine set point dosage adjustment.

\subsubsection{Statistical Analysis}

Statistical calculations were performed using PASW statistics version 25.0 (SPSS Inc, Chicago, IL, USA). Logarithmic transformations were used to normalize the bacteriological data, and the results are presented as geometric mean values. The chi-square test and one-way analysis of variance (ANOVA) with the Bonferroni test were applied, whenever necessary.

\section{Results}

Only 22 out of 550 samples (4.0\%), collected over 5 years from the monochloramine-treated hot water networks, were culture-positive for Legionella spp. at low levels (geometric mean $1.9 \times 10^{2} \mathrm{cfu} / \mathrm{L}$ ), although most isolates $(13 / 22,59.1 \%)$ belonged to serogroup 1 . Table 1 reports the numbers and percentages of Legionella positive samples and their geometric means, together with the mean values of monochloramine, temperature, and $\mathrm{pH}$, according to the four treated pipelines. Water pipework significantly affected the percentage of positive samples $\left(\chi^{2}=12.656, p<0.005\right)$ but not their bacterial load $(F=2.294, n s)$. Network $C$ showed the lowest percentage, followed by the $A, B$, and E pipeworks, but all of them, ranging from 0.8 to $9.1 \%$, were largely below $30 \%$ - a value reported as being an indicator of low risk for disease transmission. No significant difference in monochloramine mean concentration was found between water networks, even if 25/136 samples (18.4\%) in loop B had a monochloramine content $>4 \mathrm{mg} / \mathrm{L}$, compared to $22 / 172(12.8 \%), 12 / 121(9.9 \%)$, and 8/121 (6.6\%) in the A, C and E loops, respectively. Network A had a mean temperature significantly higher than the other networks $\left(p<0.05\right.$ by the Bonferroni test), although still in a range $\left(45-50{ }^{\circ} \mathrm{C}\right)$ that prevents the degradation of the biocide. A neutral $\mathrm{pH}$ was always found in all the treated pipelines. 
Table 1. Microbiological and physical-chemical parameters in water samples collected from the four monochloramine-treated networks.

\begin{tabular}{ccccccc}
\hline $\begin{array}{c}\text { Water } \\
\text { Pipework }\end{array}$ & $\begin{array}{c}\text { Samples } \\
\text { Number }\end{array}$ & \multicolumn{2}{c}{ Legionella spp. Positives } & \multicolumn{2}{c}{ Physical-Chemical Parameters } \\
\hline & & $n /$ Total (\%) a & $\begin{array}{c}\text { Geometric Mean cfu/L } \\
\text { (Range) }\end{array}$ & $\begin{array}{c}\text { Monochloramine } \\
\text { Mean } \pm \text { SD mg/L }\end{array}$ & $\begin{array}{c}\text { T }\left({ }^{\circ} \text { C) }\right. \\
\text { Mean } \pm \text { SD }\end{array}$ & $\begin{array}{c}\text { pH } \\
\text { Mean } \pm \text { SD }\end{array}$ \\
\hline A & 172 & $4 / 172(2.3)$ & $1.3 \times 10^{2}\left(25-2.9 \times 10^{3}\right)$ & $2.84 \pm 1.18$ & $45.3 \pm 4.5^{\mathrm{b}}$ & $7.4 \pm 0.3$ \\
B & 136 & $6 / 136(4.4)$ & $7.2 \times 10\left(25-3.0 \times 10^{2}\right)$ & $2.98 \pm 1.10$ & $39.1 \pm 6.6$ & $7.5 \pm 0.4$ \\
C & 121 & $1 / 121(0.8)$ & $2.5 \times 10^{3}$ & $2.82 \pm 0.95$ & $40.9 \pm 5.0$ & $7.4 \pm 0.2$ \\
E & 121 & $11 / 121(9.1)$ & $2.9 \times 10^{2}\left(25-3.2 \times 10^{3}\right)$ & $2.93 \pm 0.90$ & $40.7 \pm 8.1$ & $7.5 \pm 0.2$ \\
Total & 550 & $22 / 550(4.0)$ & $1.9 \times 10^{2}\left(25-3.2 \times 10^{3}\right)$ & $2.89 \pm 1.05$ & $41.8 \pm 6.6$ & $7.4 \pm 0.3$ \\
\hline
\end{tabular}

$\mathrm{SD}=$ Standard Deviation ${ }^{\mathrm{a}} p<0.005^{\mathrm{b}} p<0.05$ A vs. all the other networks.

$\mathrm{N}$-nitrosamines were all below the LOD in monochloramine and chlorine dioxide-treated and untreated water, as well as in the cold water entering the hospital buildings.

Chlorites were only detected in July 2015, in the A and B loops, when the chlorine dioxide devices were still operating before the application of monochloramine (1764 and $1748 \mu \mathrm{g} / \mathrm{L}$, respectively).

Chlorates ranged between LOD $(<60)$ and $352 \mu \mathrm{g} / \mathrm{L}$ in cold water, and between LOD $(<60)$ and $240 \mu \mathrm{g} / \mathrm{L}$ in the untreated hot water loop. In the monochloramine-treated pipelines, chlorate concentrations were always higher than the WHO value of $700 \mu \mathrm{g} / \mathrm{L}$ during the first 2 years of the study, without any significant differences between the four devices (Figure 2A). Within the same time frame, the ammonia concentrations of the treated samples increased compared to untreated hot water and cold water (Figure 2B). In light of these results, corrective actions were regularly taken over the next 3 years, as previously described (see the chapter on Corrective actions). As a result, since 2017 the chlorates decreased below the WHO provisional value in all the water networks, and free ammonia below $0.50 \mathrm{mg} / \mathrm{L}$, with the exception of pipeline B for the first months of 2017 (Figure 2A,B).

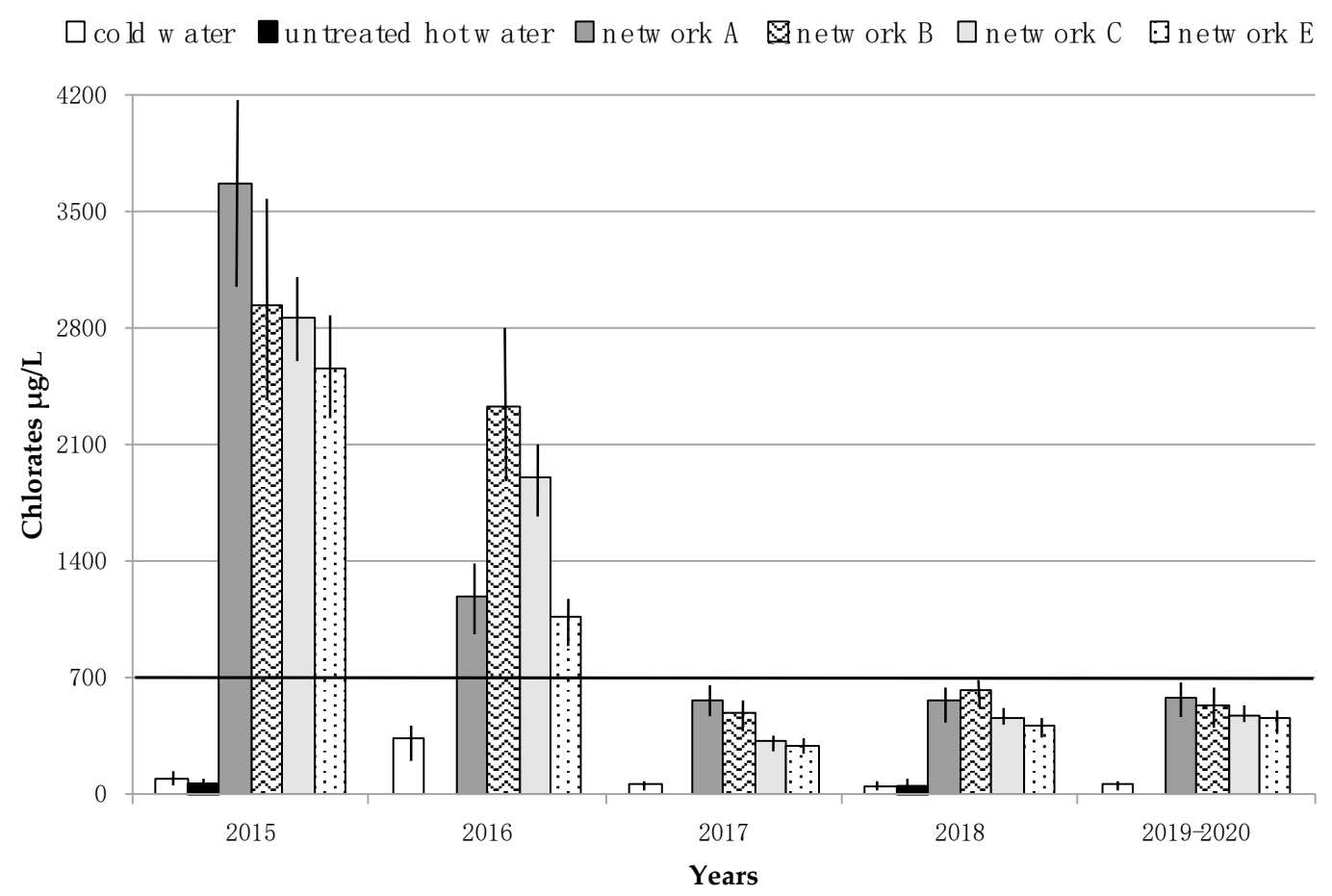

(A)

Figure 2. Cont. 


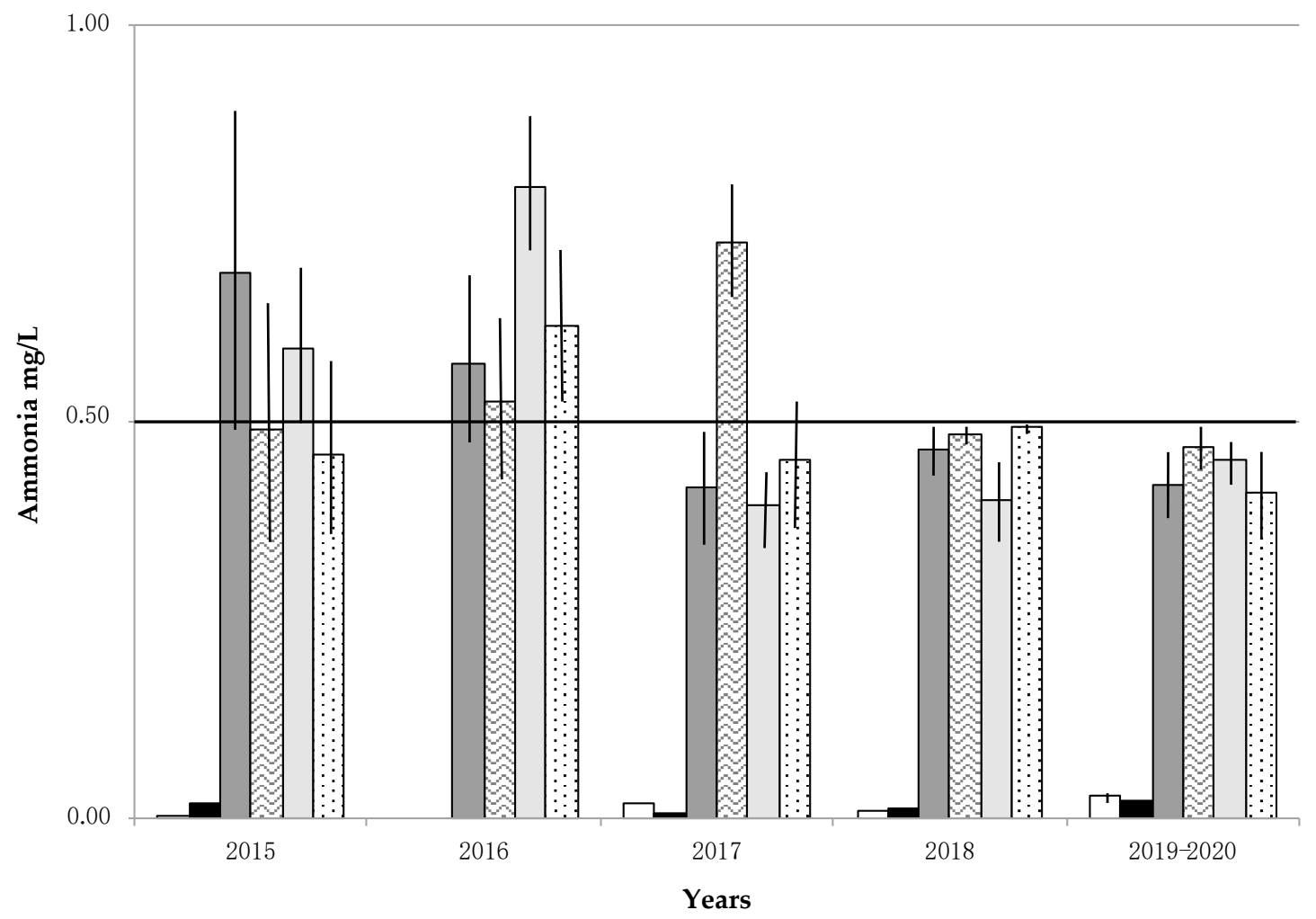

(B)

Figure 2. Trend of chlorates (A) and ammonia (B) expressed as mean \pm Standard Deviation (SD) according to sampling sessions and water pipelines. Black line $(700 \mu \mathrm{g} / \mathrm{L})$ indicates the provisional value for chlorate in drinking water, established by WHO. Black line $(0.50 \mathrm{mg} / \mathrm{L})$ indicates the maximum permissible drinking water ammonium value established by Italian and European legislation.

TOC concentrations were below the LOD in $63 \%$ of the samples, and at very low levels $(0.1-0.3 \mathrm{mg} / \mathrm{L})$ in the remaining. THMs were extremely low as they were $<1 \mu \mathrm{g} / \mathrm{L}$ for all systems. In all the sample nitrites and nitrates were below the limits imposed by Italian and European regulations (range $0.001-0.072 \mathrm{mg} / \mathrm{L}$ and $4.30-22.00 \mathrm{mg} / \mathrm{L}$, respectively), and they did not increase in the presence of monochloramine.

\section{Discussion}

Our findings confirm the long-term effectiveness of the monochloramine device operating since 2009 in controlling Legionella contamination, as reported in previous studies [15,17,30,31]. Similarly, the monochloramine devices installed at the beginning of this study, in two water networks previously treated with chlorine dioxide, proved to be effective. Indeed, approximately 30\% (60 positives/201 samples) of the samples taken from these pipelines over the three-year period, before chlorine dioxide was replaced with monochloramine, tested positive for Legionella [17]. The same effectiveness was verified in Building E, where the percentage of contamination in the period 2001-June 2012, before the installation of the monochloramine device, was $89.9 \%$ (80/89 samples), falling to $11.6 \%$ (21/181) over the eight years following its placement. The monochloramine effectiveness is also confirmed, irrespective of biocide injection point. However, injecting monochloramine into the cold make-up water could lead to a more difficult control of biocide concentration, as highlighted by the higher percentage of samples exceeding the maximum contaminant level established by the EPA in loop B. In light of this observation, it could be advisable to dose monochloramine directly in the hot water loop. Three chloramines are produced when chlorine reacts with ammonia in water: monochloramine, 
dichloramine, and trichloramine. Monochloramine is generally the predominant species at neutral $\mathrm{pH}$ and above [32,33]. As $\mathrm{pH}$ plays a key role in the formation of the monochloramine from precursors, recurring $\mathrm{pH}$ values above 7.0 prove that monochloramine is the predominant species in our system, without any formation of toxic and odorous di- and tri-chloramines.

To our knowledge, this is the first study that includes nitrosamines in the assessment of the formation of potentially dangerous DBPs during long-term monochloramine treatment in small-scale plants. In our hospital, no formation of the most prevalent N-nitrosamines was observed, even in the hot-water treated with monochloramine for nine years.

The low levels of nitrosamine precursors such as TOC, nitrites, and nitrates found in the hospital tap water may explain this satisfactory result. Indeed, it is known that $\mathrm{N}$-nitrosamine formation during water treatment requires the presence of organic nitrogen-containing precursors [20-22,34]. The presence of nitrite in a water supply is undesirable because of health concerns (e.g., methaemoglobinaemia in infants) [29]. In our study, no increase in nitrite levels occurred by using monochloramine, thus supporting the safety of this biocide.

The measured THMs concentrations were extremely low in all water networks, which was in line with the results of our previous study where, in addition to THMs, haloacetic acids were also investigated, and were not detected in the network treated with monochloramine [15]. These findings confirm in a small-scale hot-water system what has already been observed in drinking water, namely that using monochloramine instead of free chlorine as a residual disinfectant minimizes the formation of these regulated toxic DBPs $[13,14]$.

Congenital anomalies, the impairment of neurobehavioral and neurological development, the delay in female sexual development, soft tissue anomalies, and altered thyroid function were observed in association with chlorate exposure via drinking water [35]. Chlorate formation in chloraminated water is due to hypochlorite degradation when it is improperly stored and/or of poor quality [29]. Therefore, we suggest using a stable formulation of hypochlorite, and replacing this precursor frequently with a fresh product, in order to avoid the incomplete reaction of monochloramine precursors and the unintended build-up of chlorates and free ammonia. Routine monitoring of free ammonia is also recommended because ammonia can compromise disinfection efficiency, can lead to nitrite formation in distribution systems, and can cause the failure of manganese removal filters, as well as taste and odor problems. Other authors have observed nitrification in water due to a non-stoichiometric dosage of the monochloramine precursors, and the re-growth of denitrifying bacteria following long-term treatment in hospital [36]. However, the limited increase in free ammonia, above the EU drinking water standard of $0.50 \mathrm{mg} / \mathrm{L}$, is not relevant to public health. Indeed, ammonia in water is an indicator of possible bacterial, sewage, and animal waste pollution, and exposure from environmental sources is considered insignificant in comparison with the endogenous synthesis of ammonia [29].

We emphasize that monochloramine does not produce chlorites, which are regulated at national and international level due to their toxicity [35]. This is another aspect supporting the use of monochloramine as an alternative to chlorine dioxide.

A limitation of this study is the lack of information on the potential presence of other DBPs, such as haloketones, chloropicrin, aldehydes, etc., previously found in water treated with monochloramine [37], but not currently regulated by the EU Drinking Water Directive. Another limitation is its monocentric nature. The single-hospital setting may limit the generalizability of the results. Further research is required for dealing with these issues.

\section{Conclusions}

National and international guidelines recommend controlling Legionella spp. contamination, with particular reference to healthcare structures. Disinfection procedures are required to prevent or control the risk of Legionella water contamination, and each procedure has different advantages, as well as maybe posing a risk to human health. 
Thanks to our decades of experience in the use of monochloramine for the control of Legionella spp. contamination in different water systems of the same hospital, we can affirm that this biocide, if properly produced, continuously dosed, and regularly maintained is extremely effective against Legionella and does not produce any toxic disinfection by-products, such as nitrosamines and chlorites, or nitrification.

In conclusion, our study confirms that monochloramine may be proposed as an effective and safe strategy for the continuous disinfection of building plumbing systems, preventing vulnerable individuals from being exposed to legionellae and to dangerous DBPs.

Author Contributions: Conceptualization, I.M., P.B. and A.B.; formal analysis, I.M. and S.P.; funding acquisition, P.B.; investigation, G.F., P.Z. and G.O.C.; methodology, I.M. and S.P.; project administration, A.B.; resources, L.S., E.V., G.O.C. and M.F.; supervision, M.F., P.B. and A.B.; visualization, I.M.; writing-original draft, I.M., S.P. and A.B.; writing-review and editing, I.M. and A.B. All authors have read and agree to the published version of the manuscript.

Funding: This research received no external funding.

Conflicts of Interest: The authors declare no conflict of interest.

\section{References}

1. Lin, Y.E.; Stout, J.E.; Yu, V.L. Prevention of hospital-acquired legionellosis. Curr. Opin. Infect. Dis. 2011, 24, 350-356. [CrossRef]

2. Superior Institute of Health. Italian Guidelines for Prevention and Control of Legionellosis; Approvate in Conferenza Stato-Regioni nella seduta del 7 maggio 2015; Superior Institute of Health: Rome, Italy, 2015.

3. WHO. Legionella and the Prevention of Legionellosis; World Health Organization: Geneva, Switzerland, 2007.

4. Borella, P.; Bargellini, A.; Marchegiano, P.; Vecchi, E.; Marchesi, I. Hospital-acquired Legionella infections: An update on the procedures for controlling environmental contamination. Ann. Ig. 2016, 28, 98-108. [PubMed]

5. Ngwenya, N.; Ncube, E.J.; Parsons, J. Recent advances in drinking water disinfection: Successes and challenges. Rev. Environ. Contam. Toxicol. 2013, 222, 111-170. [PubMed]

6. Nieuwenhuijsen, M.J.; Smith, R.; Golfinopoulos, S.; Best, N.; Bennett, J.; Aggazzotti, G.; Righi, E.; Fantuzzi, G.; Bucchini, L.; Cordier, S.; et al. Health impacts of long-term exposure to disinfection by-products in drinking water in Europe: HIWATE. J. Water Health 2009, 7, 185-207. [CrossRef] [PubMed]

7. Plewa, M.J.; Richardson, S.D. Water treatment and disinfection by-products. J. Environ. Sci. 2017, 58, 1-350. [CrossRef]

8. Pule, D. Conventional and alternative disinfection methods of Legionella in water distribution systems-Review. Constr. Sci. 2016, 19, 21-26. [CrossRef]

9. Giovanardi, R.; Bononi, M.; Messori, M.; Bargellini, A.; Paduano, S.; Borella, P.; Marchesi, I. Corrosion resistance of commonly used plumbing materials for water distribution systems exposed to disinfection treatments. Corros. Eng. Sci. Technol 2020, 1-8. [CrossRef]

10. Dice, J.C. Denver's seven decades of experience with chloramination. J. Am. Water Works Assoc. 1985, 77, 34-37. [CrossRef]

11. Kool, J.L.; Carpenter, J.C.; Fields, B.S. Effect of monochloramine disinfection of municipal drinking water on risk of nosocomial Legionnaires' disease. Lancet 1999, 353, 272-277. [CrossRef]

12. Heffelfinger, J.D.; Kool, J.L.; Fridkin, S.; Fraser, V.J.; Hageman, J.; Carpenter, J.; Whitney, C.G. Society for Healthcare Epidemiology of America. Risk of hospital-acquired legionnaires' disease in cities using monochloramine versus other water disinfectants. Infect. Control Hosp. Epidemiol. 2003, 24, 569-574. [CrossRef]

13. Flannery, B.; Gelling, L.B.; Vugia, D.J.; Weintraub, J.M.; Salerno, J.J.; Conroy, M.J.; Stevens, V.A.; Rose, C.E.; Moore, M.R.; Fields, B.S.; et al. Reducing Legionella colonization in water systems with monochloramine. Emerg. Infect. Dis. 2006, 12, 588-596. [CrossRef] [PubMed]

14. Moore, M.R.; Pryor, M.; Fields, B.; Lucas, C.; Phelan, M.; Besser, R.E. Introduction of monochloramine into a municipal water system: Impact on colonization of buildings by Legionella spp. Appl. Environ. Microbiol. 2006, 72, 378-383. [CrossRef] [PubMed] 
15. Marchesi, I.; Ferranti, G.; Bargellini, A.; Marchegiano, P.; Predieri, G.; Stout, J.E.; Borella, P. Monochloramine and chlorine dioxide for controlling Legionella pneumophila contamination: Biocide levels and disinfection by-products formation in hospital water networks. J. Water Health 2013, 11, 738-747. [CrossRef] [PubMed]

16. Duda, S.; Kandiah, S.; Stout, J.E.; Baron, J.L.; Yassin, M.; Fabrizio, M.; Ferrelli, J.; Hariri, R.; Wagener, M.M.; Goepfert, J.; et al. Evaluation of a new monochloramine generation system for controlling Legionella in building hot water systems. Infect. Control Hosp. Epidemiol. 2014, 35, 1356-1363. [CrossRef] [PubMed]

17. Marchesi, I.; Ferranti, G.; Mansi, A.; Marcelloni, A.M.; Proietto, A.R.; Saini, N.; Borella, P.; Bargellini, A. Control of Legionella contamination and risk of corrosion in hospital water networks following various disinfecting procedures. Appl. Environ. Microbiol. 2016, 82, 2959-2965. [CrossRef] [PubMed]

18. Coniglio, M.A.; Ferrante, M.; Yassin, M.H. Preventing Healthcare-Associated Legionellosis: Results after 3 Years of Continuous Disinfection of Hot Water with Monochloramine and an Effective Water Safety Plan. Int. J. Environ. Res. Public Health 2018, 15, 1594. [CrossRef] [PubMed]

19. Simoes, L.C.; Simoes, M. Biofilms in drinking water: Problems and solutions. RSC Adv. 2013, 3, $2520-2533$. [CrossRef]

20. Nawrocki, J.; Andrzejewski, P. Nitrosamines and water. J. Hazard. Mater. 2011, 189, 1-18. [CrossRef]

21. Kadmi, Y.; Favier, L.; Wolbert, D. N-nitrosamines, emerging disinfection by-products of health concern: An overview of occurrence, mechanisms of formation, control and analysis in water. Water Sci. Technol. 2015, 15, 11-25. [CrossRef]

22. West, D.M.; Wu, Q.; Donovan, A.; Shi, H.; Ma, Y.; Jiang, H.; Wang, J. N-nitrosamine formation by monochloramine, free chlorine, and peracetic acid disinfection with presence of amine precursors in drinking water system. Chemosphere 2016, 153, 521-527. [CrossRef]

23. Qiu, Y.; Bei, E.; Wang, Y.; Wang, J.; Zhang, X.; Chen, C. One representative water supply system in China with nitrosamine concern: Challenges and treatment strategies. J. Environ. Sci. 2020, 88, 12-20. [CrossRef] [PubMed]

24. US Environmental Protection Agency (EPA). Drinking Water Standards and Health Advisories; 822-S-12-001; EPA: Washington, DC, USA, 2012.

25. Krasner, S.W.; Kostopoulou, M.; Toledano, M.B.; Wright, J.; Patelarou, E.; Kogevinas, M.; Villanueva, C.M.; Carrasco-Turigas, G.; Santa Marina, L.; Fernández-Somoano, A.; et al. Occurrence of DBPs in Drinking Water of European Regions for Epidemiology Studies. J. Am. Water Works Assoc. 2016, 108, E501-E512. [CrossRef]

26. Mitch, W.A.; Gerecke, A.C.; Sedlak, D.L. A N-Nitrosodimethylamine (NDMA) precursor analysis for chlorination of water and wastewater. Water Res. 2003, 37, 3733-3741. [CrossRef]

27. Decreto Legislativo 2 Febbraio 2001 n. 31, e Successive Modifiche. Attuazione della Direttiva 98/83/CE Relativa alla Qualità delle Acque Destinate al Consumo Umano. Gazzetta Ufficiale n. 52 del 3.3.2001, Supplemento Ordinario n. 41. Available online: https://www.gazzettaufficiale.it/eli/id/2001/03/03/001G0074/sg (accessed on 1 July 2020).

28. Council Directive 98/83/EC of 3 November 1998 on the quality of water intended for human consumption. Off. J. Eur. Union 1998, 330, 32-54.

29. WHO. Guidelines for Drinking-Water Quality. In Incorporating the First Addendum, 4th ed.; World Health Organization: Geneva, Switzerland, 2017.

30. Marchesi, I.; Cencetti, S.; Marchegiano, P.; Frezza, G.; Borella, P.; Bargellini, A. Control of Legionella contamination in a hospital water distribution system by monochloramine. Am. J. Infect. Control 2012, 40, 279-281. [CrossRef]

31. Paduano, S.; Marchesi, I.; Casali, M.E.; Valeriani, F.; Frezza, G.; Vecchi, E.; Sircana, L.; Romano Spica, V.; Borella, P.; Bargellini, A. Characterisation of microbial community associated with different disinfection treatments in hospital hot water networks. Int. J. Environ. Res. Public Health 2020, 17, 2158. [CrossRef]

32. White, G.C. Handbook of Chlorination for Potable Water, Wastewater, Cooling Water, Industrial Processes, and Swimming Pools; Van Nostrand Reinhold: New York, NY, USA, 1972.

33. Melada, S.; Coniglio, M.A. Monochloramine for remediation of Legionella only in domestic hot water systems: An iron fist in a velvet glove. Open J. Prev. Med. 2015, 5, 143-150. [CrossRef]

34. Qi, W.; Fang Yee, L.; Jiangyong, H. Relationship between organic precursors and N-nitrosodimethylamine (NDMA) formation in tropical water sources. J. Water Health 2014, 12, 736-746. [CrossRef] 
35. Righi, E.; Bechtold, P.; Tortorici, D.; Lauriola, P.; Calzolari, E.; Astolfi, G.; Nieuwenhuijsen, M.J.; Fantuzzi, G.; Aggazzotti, G. Trihalomethanes, chlorite, chlorate in drinking water and risk of congenital anomalies: A population-based case-control study in Northern Italy. Environ. Res. 2012, 116, 66-73. [CrossRef]

36. Casini, B.; Baggiani, A.; Totaro, M.; Mansi, A.; Costa, A.L.; Aquino, F.; Miccoli, M.; Valentini, P.; Bruschi, F.; Lopalco, P.L.; et al. Detection of viable but non-culturable legionella in hospital water network following monochloramine disinfection. J. Hosp. Infect. 2018, 98, 46-52. [CrossRef]

37. Vu, T.N.; Kimura, S.Y.; Plewa, M.J.; Richardson, S.D.; Marinas, B.J. Predominant N-haloacetamide and haloacetonitrile formation in drinking water via the aldehyde reaction pathway. Environ. Sci. Technol. 2019, 53, 850-859. [CrossRef] [PubMed]

(C) 2020 by the authors. Licensee MDPI, Basel, Switzerland. This article is an open access article distributed under the terms and conditions of the Creative Commons Attribution (CC BY) license (http://creativecommons.org/licenses/by/4.0/). 